\title{
Efficiency Improvement of CZTSe Solar Cell with Ag Doped Zno/Cds Buffer Layer, using Scaps Simulation Programme
}

\author{
Kajal Mukhopadhyay, P. Fermi Hilbert Inbaraj, J. Joseph Prince
}

\begin{abstract}
Compound semiconductor CZTSe is a popular absorber layer for thin film solar cells. Instead of single semiconductor buffer layer, a hybrid buffer layer is used with CZTSe absorber layer. To reduce further usage of toxic materials(CdS) and simultaneously to increase the solar cell efficiency, Ag doped buffer layer was proposed and a numerical studies were performed using SCAPS 1-D simulation programme. Also the thickness and the carrier density of the different layers in the solar cell were optimized to achieve the above goals. After the simulation process, the toxic materials usage was reduced by $62 \%$ and the efficiency was increased from $12.24 \%$ to $12.69 \%$.
\end{abstract}

Key words- CZTSe, Ag doping, Buffer layer, SCAPS, Efficiency

\section{INTRODUCTION:}

The solar photo voltaic energy source is one of the best alternate energy sources at present. The Si-wafer based photo voltaic solar cell is the most popularly used cell but it is not very economic. The thin film solar cell is an economic solution to this problem. Thin film solar cells not only consume less material, its manufacturing process enables large area modules to be made, and does not require high temperature. Thus, the manufacture of thin film solar cells cost much lower than that of Si-wafer based solar cells[1]. The criteria for selecting the solar cell materials are based on availability of process technology, as well as the availability, cost and eco-friendliness of the raw materials. However, thin film solar-cells are less efficient than Si solar cell. In the author's previous work[2], with $\mathrm{CZTSe} / \mathrm{CdS} / \mathrm{n}$ $\mathrm{ZnO} / \mathrm{i}-\mathrm{ZnO}$ solar cell, buffer layer thickness was optimized at $\mathrm{CdS}=65 \mathrm{~nm}, \mathrm{n}-\mathrm{ZnO}=15 \mathrm{~nm}$ and an efficiency of $12.24 \%$ was obtained using SCAPS simulation program. The goals of this simulation are: i) to increase the efficiency, ii) to reduce the usage of toxic materials, and iii) to reduce overall materials used, using SCAPS simulation program. The following methods have been used to achieve the above objectives, i ) fine tuning the band gap of buffer layer which will in turn improve the carrier generation, ii) fine tuning the thickness of different layers which can improve the carrier generation and reduce recombination, iii) fine tuning the

Revised Manuscript Received on July 18, 2019.

Kajal Mukhopadhyay, Department of Electronics and Communication Engineering, Dayananda Sagar college of Engineering, Bangalore, Karnataka-560078, India. (E-mail: mukhopadhyaykajal2@gmail.com)

P. Fermi Hilbert Inbaraj, Department of Physics, Bharathidasan Institute of Technology (BIT) Campus, Anna University, Tiruchirappalli620024 , India.

J. Joseph Prince, Department of Physics, Bharathidasan Institute of Technology (BIT) Campus, Anna University, Tiruchirappalli-620024, India. carrier concentrations to improve carrier generation and reduce recombination.

\section{DEVICE MODELLING :}

In solar radiation, photons have different energies. Hence solar radiation can be converted more efficiently into electrical energy if different band gap materials are used in solar cell. As the energy of the photon increases, the band gap of the material required to convert it must also increase. Semiconductor with high band gap is placed at the front side as the high energy photons are converted first; consequently, the semiconductor with low band gap is placed at the rear. Based on the above principle, two types of solar cells can be designed : hetero junction and multi-junction. A hetero junction solar cell has been designed in this work. Fig.-1 shows a diagram of the proposed model.

\begin{tabular}{|c|c|}
\hline Window Layer & i-Zno \\
\hline Hybrid Buffer Layer & $\begin{array}{l}\text { Zno } \\
\text { CdS }\end{array}$ \\
\hline Absorber Layer & CZTS \\
\hline Back Contact & \\
\hline
\end{tabular}

Figure-1: A model of thin film solar cell

\section{i) Window layer:}

This layer should be transparent to the incident radiation and conducting enough to collect the charge carrier. $\mathrm{i}-\mathrm{ZnO}$ has all the required properties for a window layer, including the band gap of $3.3 \mathrm{eV}$ [3][12]. Thus, for the window layer, $\mathrm{i}-\mathrm{ZnO}$ was considered.

\section{ii) Buffer layer:}

A solar cell is a p-n junction diode, and the p-type CZTSe is being used as the absorber layer (see 2.(iii)). Thus, an ntype semiconductor layer must be used as the buffer layer. For higher efficiency, the buffer and absorber layers must have their conduction bands aligned[1]. CdS with band gap of $2.4 \mathrm{eV}$ was found to be a suitable buffer layer with CZTSe

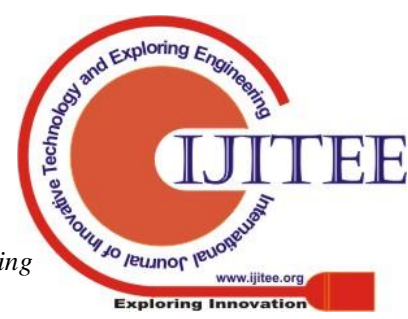




\section{EFFICIENCY IMPROVEMENT OF CZTSE SOLAR CELL WITH AG DOPED ZNO/CDS BUFFER LAYER, USING SCAPS SIMULATION PROGRAMME}

absorber layer for better band alignment[2]. However, since $\mathrm{CdS}$ is a toxic material, to reduce its usage, some amount of $\mathrm{ZnO}$ is added to the buffer layer. This hybrid of $\mathrm{ZnO}$ and $\mathrm{CdS}$ is used as the buffer layer to improve the overall efficiency. At the front side, closer to the window layer, n$\mathrm{ZnO}$ with band gap of $3.3 \mathrm{eV}$ was used and then $\mathrm{CdS}$ layer with band gap of $2.4 \mathrm{eV}$ was used.

Zinc Oxide is available aplenty in nature and is non-toxic in nature, thus becoming an attractive material for developing the next generation solar cell. It has a stable Wurtzite structure. The following deposition techniques are used to deposit $\mathrm{ZnO}$ films: Electrochemical-deposition, CVD (chemical vapour deposition), Radio Frequency magnetron sputtering method, sol-gel, etc[4],[23]. Generally, to adjust the properties of $n-\mathrm{ZnO} / \mathrm{CdS}$, doping with noble metals like $\mathrm{Ag}$ and $\mathrm{Au}$ are used[6]. The ionization energy of $\mathrm{Ag}$ is less than $\mathrm{Au}$, hence $\mathrm{Ag}$ was used for doping $\mathrm{ZnO} / \mathrm{CdS}[5]$. With the increase of $\mathrm{Ag}$ concentration in $\mathrm{ZnO}$, the absorption band edges shifted to longer wavelengths which means there is a decrease in the band gap of the $\mathrm{ZnO}$ after doping with $\mathrm{Ag}$ [4],[5].With the increase in $\mathrm{Ag}$ at $10.3 \mathrm{wt} \%$, the band gap reduced from $3.28 \mathrm{eV}$ to $2.65 \mathrm{eV}$; the band gap decreases with further doping[7]. Minority carrier concentration at equilibrium decreases with increase in doping density. So if we increase the doping density, minority carrier concentration decreases and open circuit voltage increases. At the same time, high doping density increases carrier recombination which reduces $\mathrm{V}_{\mathrm{oc}}$. The doping density of the absorber and buffer layers need to be optimized to obtain maximum open circuit voltage.

The optical properties of $\mathrm{Ag}$ doped $\mathrm{CdS}$ thin film made using the spray pyrolysis process were studied by M. A. Khalid et al., who reported that with the variation of doping concentration range (0-2.5) $\mathrm{wt} \%$ the energy gap varies from $2.4 \mathrm{eV}$ to $2.21 \mathrm{eV}$ [8]. Shubham Chandel et al. reported that, the band gap of $\mathrm{CdS}$ was reduced from $2.49 \mathrm{eV}$ to $2.33 \mathrm{eV}$ after Ag doping[10]. Ag acts as an acceptor dopant and reduces the band gap of CdS. Sergio R. Ferra-Gonzalez had studied how the band gap of $\mathrm{CdS}$ thin film varies with changing concentration of $\mathrm{Ag}$. $\mathrm{CdS}$ was deposited in a chemical bath as thin films and doped with Ag. Here, the band gap variation lay between 2.31 and $2.51 \mathrm{eV}$ [11]. In this pioneering work, $\mathrm{Ag}$ doped $\mathrm{CdS} / \mathrm{ZnO}$ hybrid buffer layer was used for fine tuning the band gap.

\section{iii) Absorption layer:}

Copper Zinc Tin Selenium $\left(\mathrm{Cu}_{2} \mathrm{ZnSnSe}\right)$ is an ideal material to use as an absorption layer. It has a suitable band gap of $0.95 \mathrm{eV}$, it is an eco-friendly material, and all the constituents of CZTS are available in plenty at a low cost[26]. The manufacturing process is also cost effective[3]. CZTSe has a high absorption coefficient because electron-hole pair generation is more probable, as the bottom of the conduction band and the top of the valence band match. The carrier mobility and carrier life time is also high for CZTS. Between the kesterite and stannite phases of CZTS, the former phase is more stable. In the CZTS crystal structure there are mainly $\mathrm{Zn}$ vacancies and $\mathrm{Cu}$ atoms occupy the $\mathrm{Zn}$ vacancy sites, thus making it a p-type material. The $\mathrm{Cu} / \mathrm{Zn}$ ratio can be varied in order to control the conductivity of this layer.

\section{SCAPS}

One dimensional solar cell can be simulated by Solar cell capacitance simulator (SCAPS). Poisson equations and continuity equations are solved in this simulation programme. The electrical parameters such as: open circuit voltage $\left(\mathrm{V}_{\mathrm{oc}}\right)$, short circuit current $\left(\mathrm{I}_{\mathrm{sc}}\right)$, fill factor $(\mathrm{FF})$, capacitance voltage spectroscopy, quantum efficiency, generation and recombination profiles and carrier current densities are calculated at different temperatures. Other parameters, such as dielectric constant, refractive index, absorption constant, etc., are also used in this simulation process. Parameters of particular interest are the band to band recombination, defects and interface thickness, series and shunt resistance of the cell. A maximum of seven semiconductor layers with front contacts and back contacts can simulated in SCAPS. The specification parameters of the materials associated with each solar cell layer are given as input to the simulation program [13], [14].

\section{DEVICE SIMULATIONS}

In the SCAPS simulation process, all the design parameters are loaded and the measuring parameters along with test conditions are specified. The basic material parameters, the optical and defects parameters and Front and back contact material parameters are presented in this author's previous work[2]. The band gap, layer thickness and carrier density are given in Table-1. For fine tuning the carrier concentration, three different combinations of CZTSe-acceptor density and $\mathrm{CdS} / \mathrm{ZnO}$-donor density were considered in the simulation, as shown in Table-1. In the author's previous work, the optimized total buffer layer thickness was found to be $80 \mathrm{~nm}$ and the same was used here[2]. The total buffer layer thickness was considered constant at $80 \mathrm{~nm}$ in this simulation process and then five combinations of the thicknesses of the $\mathrm{ZnO} / \mathrm{CdS}$ layer were considered. Solar radiation at AM1.5 $\left(1000 \mathrm{~W} / \mathrm{cm}^{2}\right)$ was used for the simulations. A shunt Resistance of $400 \Omega \mathrm{cm}^{2}$, series resistance of $4.25 \Omega \mathrm{cm}^{2}$ and an ambient temperature of $300 \mathrm{~K}$ were considered for this simulation. 
Table-1: Bandgap, layer thickness and carrier density of the solar cell materials

\begin{tabular}{|c|c|c|c|c|c|c|}
\hline Parameters & Unit & CZTSe & $\mathrm{ZnO}$ & $\mathrm{CdS}$ & $\mathrm{i}-\mathrm{ZnO}$ & \\
\hline 1.Band gap & $\mathrm{eV}$ & 0.95 & 3.3 & 2.4 & 3.3 & ] \\
\hline 2.Thickness ( uniform layer) & $\mathrm{nm}$ & 2600 & \multicolumn{2}{|c|}{ Total thickness 80} & 40 & {$[2][25]$} \\
\hline $\begin{array}{l}\text { 3.Uniform Acceptor/ Donor } \\
\text { density }\end{array}$ & $\mathrm{cm}^{-3}$ & $1000 \mathrm{E}+16$ & $1.00 \mathrm{E}+17$ & $1.00 \mathrm{E}+17$ & $5.00 \mathrm{E}+17$ & Set-1 \\
\hline & & $1000 \mathrm{E}+17$ & $1.00 \mathrm{E}+18$ & $1.00 \mathrm{E}+18$ & $5.00 \mathrm{E}+17$ & Set-2 \\
\hline & & $1000 \mathrm{E}+17$ & $1.00 \mathrm{E}+17$ & $1.00 \mathrm{E}+18$ & $5.00 \mathrm{E}+17$ & Set-3 \\
\hline
\end{tabular}

\section{RESULTS:}

In Fig.2, the $\mathrm{ZnO}$ - thickness is on the $\mathrm{x}$-axis (unit: 20nm), CdS- thickness is on the y-axis (unit: 20nm) and solar cell efficiency is on $\mathrm{Z}$-axis (relative to $12 \%$ ). Five combinations of $\mathrm{ZnO} / \mathrm{CdS}$ thickness: 80/0, 60/20, 40/40, $20 / 60$ and $0 / 80$, were considered for each set as mentioned in Table-1. The results are shown in red, blue and yellow for sets 1, 2 and 3 respectively, of different carrier densities shown in the Table-1.

The simulation was done in five steps.

i) Step-1: The simulation results in Fig-2 shows that the set-3 has has higher efficiency for all the thickness combinations of buffer layers.

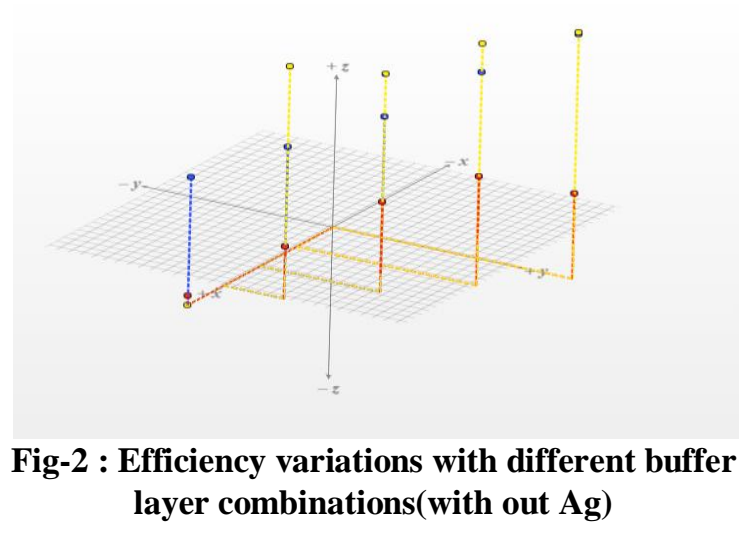

ii) Step-2: The $\mathrm{ZnO}$ buffer layer was replaced by $\mathrm{Ag}$ doped $\mathrm{ZnO}$. S.M. Hosseini et al. reported that for $\mathrm{Zn}_{1 \text { - }}$ ${ }_{x} \mathrm{Ag}_{\mathrm{x}} \mathrm{O}$ nano crystals with $\mathrm{x}=0.07$, the band gap is reduced from $3.3 \mathrm{eV}$ to $3.18 \mathrm{eV}[5]$ and the thus band gap of $\mathrm{ZnO}$ was considered as $3.18 \mathrm{eV}$ for this simulation. The results are shown in Fig-3. The efficiency of solar cell with Ag doped $\mathrm{ZnO}$ is higher when compared to $\mathrm{ZnO}$ without $\mathrm{Ag}$, for all the three sets and for all the $\mathrm{ZnO} / \mathrm{CdS}$ buffer layer thickness combinations. The results also show that the efficiency is higher for set- 3 compared to set- 1 and set- 2 . Additionally, the variation in the efficiency of $\mathrm{ZnO} / \mathrm{CdS}$ combinations are very less for set-3. The maximum efficiency of $12.63 \%$ is obtained for $\mathrm{ZnO}=60 \mathrm{~nm}$ and $\mathrm{CdS}=20 \mathrm{~nm}$ for set-3 .

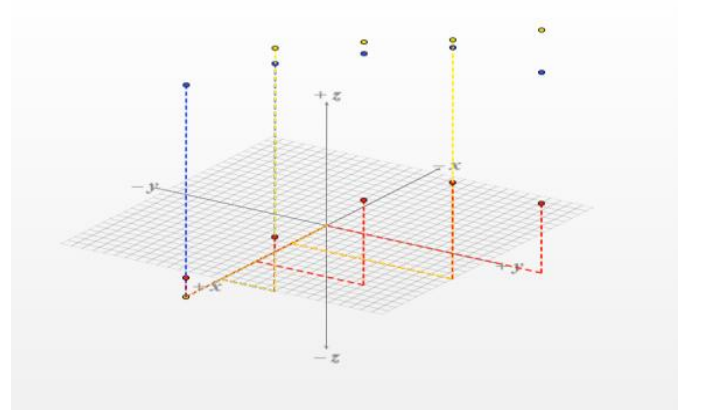

Fig-3 : Efficiency variations with different buffer layer combinations(with Ag)

iii) Step-3: The donor and acceptor density values from set-3 were used for this step of simulation, with the buffer layer thickness of $\mathrm{ZnO}=60 \mathrm{~nm}$ and $\mathrm{CdS}=20 \mathrm{~nm}$. To observe the changes in efficiency with change in the thickness of the window layer, three values of $\mathrm{i}-\mathrm{ZnO}$ thickness were used: 20,30 and $40 \mathrm{~nm}$, for which the efficiencies obtained are $12.69 \%, 12.66 \%$ and $12.63 \%$ respectively. The maximum efficiency of $12.69 \%$ was obtained for the $20 \mathrm{~nm}$ window layer and this value was used in the next step.

iv) Step-4:To reduce further material usage, a simulation was performed with $\mathrm{ZnO}=40 \mathrm{~nm}$ and the same result was obtained as with $\mathrm{ZnO}=60 \mathrm{~nm}$. Hence the $\mathrm{n}-\mathrm{ZnO}$ buffer layer thickness of 40nm was used in the next step.

v)Step-5: Ag doped CdS was considered as the buffer layer for simulation, with $\mathrm{CdS}$ band gaps of $2.3 \mathrm{eV}$ and $2.49 \mathrm{eV}$. The efficiency obtained was $12.69 \%$ for buffer layers made of both the Ag-doped and normal CdS. Hence normal $\mathrm{CdS}$ was finalized for the buffer layer to avoid unnecessary doping. Table-3 thus compares the parameters used in the initial model and those used in the final model.

Table-3: A comparison between Initial Model and Final Model

\begin{tabular}{|c|c|c|c|c|}
\hline Layer & Material & Parameter & $\begin{array}{c}\text { Initial Model } \\
(\mathbf{n}=\mathbf{1 2 . 2 3 \%})\end{array}$ & $\begin{array}{c}\text { Final Model } \\
(\mathbf{n}=\mathbf{1 2 . 6 9 \%})\end{array}$ \\
\hline 1. & $\mathrm{i}-\mathrm{ZnO}$ & Thickness(nm) & 40 & 20 \\
\hline & & Band gap(eV) & 3.3 & 3.3 \\
\hline & & Carrier density $\left(\mathrm{cm}^{-3}\right)$ & $1000 \mathrm{E}+17$ & $1000 \mathrm{E}+17$ \\
\hline
\end{tabular}


EFFICIENCY IMPROVEMENT OF CZTSE SOLAR CELL WITH AG DOPED ZNO/CDS BUFFER LAYER, USING SCAPS SIMULATION PROGRAMME

\begin{tabular}{|c|c|c|c|c|}
\hline 2. & $\mathrm{n}-\mathrm{ZnO}$ & Thickness(nm) & 15 & 40 \\
\hline & & Band gap $(\mathrm{eV})$ & 3.3 & 3.18 \\
\hline & & Carrier density $\left(\mathrm{cm}^{-3}\right)$ & $1000 \mathrm{E}+17$ & $1000 \mathrm{E}+17$ \\
\hline 3. & $\mathrm{n}-\mathrm{CdS}$ & Thickness $(\mathrm{nm})$ & 65 & 20 \\
\hline & & Band gap $(\mathrm{eV})$ & 2.4 & 2.4 \\
\hline & & Carrier density $\left(\mathrm{cm}^{-3}\right)$ & $1000 \mathrm{E}+17$ & $1000 \mathrm{E}+18$ \\
\hline 4. & $\mathrm{p}-$ CZTS & Thickness $(\mathrm{nm})$ & 2600 & 2600 \\
\hline & & Band gap $(\mathrm{eV})$ & 0.95 & 0.95 \\
\hline & & Carrier density $\left(\mathrm{cm}^{-3}\right)$ & $1000 \mathrm{E}+16$ & $1000 \mathrm{E}+17$ \\
\hline
\end{tabular}

\section{ANALYSIS:}

i) Band diagram :

Band diagram for the initial model and final model are shown in Fig4a and Fig. 4b respectively. In Fig 4a from, 0 to $2.60 \mu \mathrm{m}$ is CZTS layer and from $2.60 \mu \mathrm{m}$ to $2.665 \mu \mathrm{m}$ is CdS layer. In Fig 4b, from 0 to $2.60 \mu \mathrm{m}$ is CZTS layer and from $2.60 \mu \mathrm{m}$ to $2.62 \mu \mathrm{m}$ is $\mathrm{CdS}$ layer. In both graphs, the conduction band offset at CZTSe/CdS junction is $0.3 \mathrm{eV}$, where the maximum band offset requirement for achieving high efficiency is $0.4 \mathrm{eV}[2][24]$.

\section{Band Diagram}

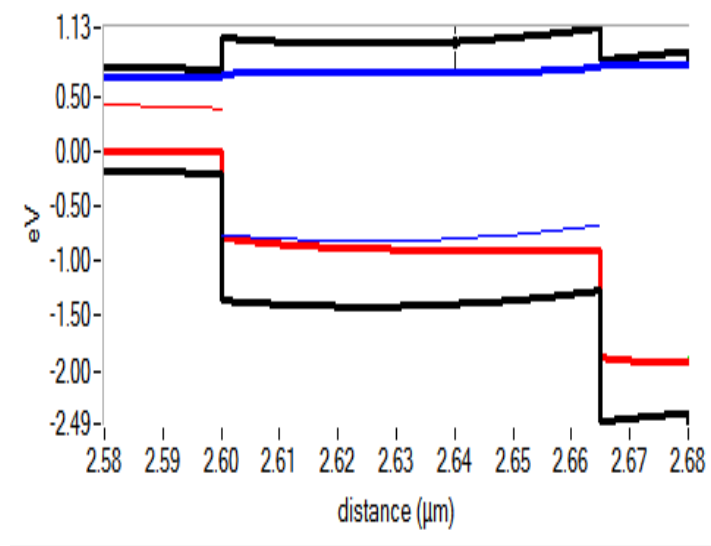

Band Diagram

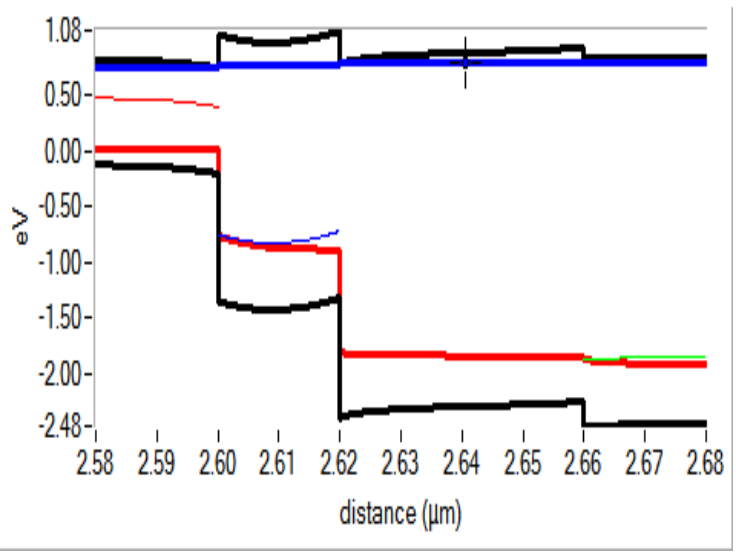

Fig 4a : Band diagram for the initial model Fig4b: Band diagram for the final model Ec and Ev -black line. EFp -red line, EFn -blue line

ii) Generation/recombination profile:
In Fig 5a, the generation/recombination profile for the initial model and in Fig 5b the generation/recombination profile for final model are shown. The e-h generation (green line) and the net generation of electrons and holes (red line) are higher in the final model compared to the initial model.

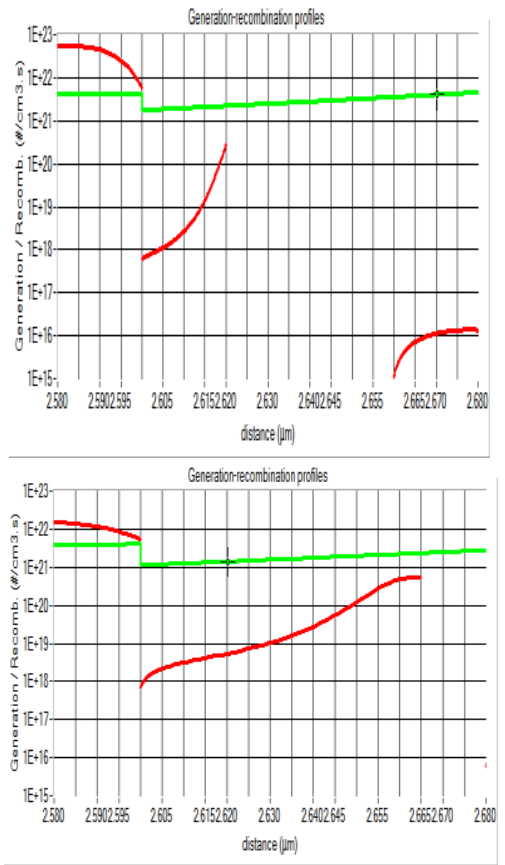

Fig5a: Gene./recomb. Profile for the initial model Fig5b: Gene./recomb profile for the final model

iii) Carrier density:

In Fig 6a and 6b,the hole carrier density (red), the electron carrier density (blue) and the total carrier density (black) are shown for the initial model and final model respectively. The total carrier density is higher in the final model compared to the initial model. 
Carrier Density

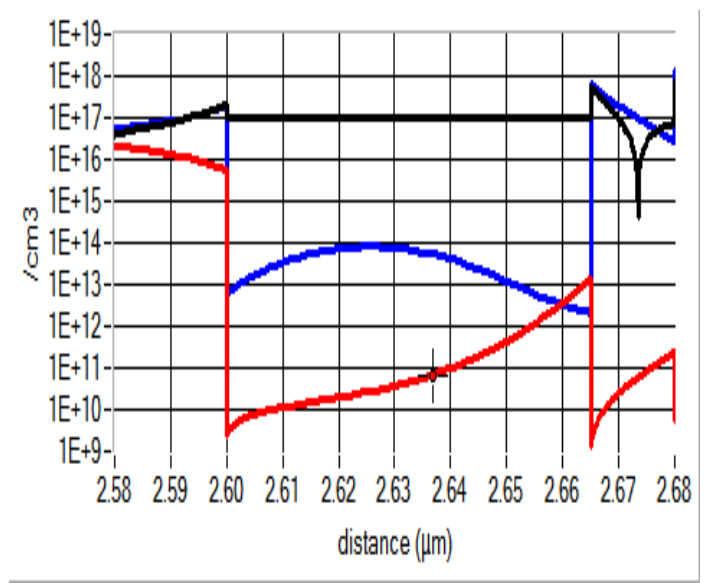

Carrier Density

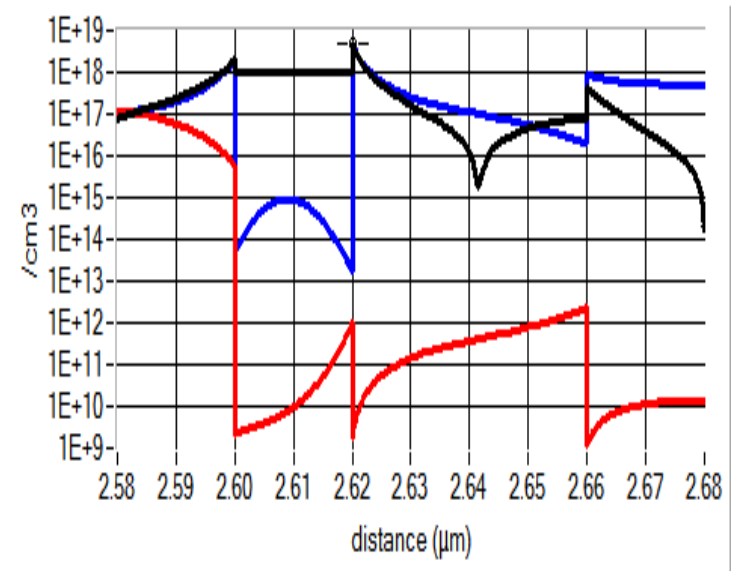

Fig 6a: Carrier density for the initial model Fig 6b: Carrier density for the final model

\section{CONCLUSION:}

The simulation was started with the parameters given in the initial model and finished with the parameters given in the final model. By using Ag doped n- $\mathrm{ZnO}$ layer, fine tuning the acceptor/donor density and optimizing the buffer layer thickness, three positive improvements were obtained: i) CdS layer thickness was reduced from $65 \mathrm{~nm}$ to $20 \mathrm{~nm}$, a $62 \%$ reduction in usage of toxic material, ii) Efficiency increased from $12.24 \%$ to $12.69 \%$, iii) Total thickness was reduced by $40 \mathrm{~nm}$.

\section{REFERENCE:}

1. Chetan Sink Solanki, Solar PhotovoltaivicFundamentals,Technologies and applications, second editions, PHI, ISBN no. 978-81-203-4386-3.

2. Kajal Mukhopadhyay, P. Fermi Hilbert Inbaraj and J. Joseph Prince .Thickness optimization of CdS/ZnO buffer layer in CZTSe thin film solar cells using SCAP simulation program. Material Research and Innovation. http://doi.org/10.1080/14328917.2018.1475907.

3. O. K. Simya et al: "A comparative study on the performance of kesterite based thin film solar cell using Scaps simulation program": superlattices and microstructures 82(2015) pp248-261.

4. Fenglin Xiang et. al. : "Characterization of $\mathrm{Ag}$ doped $\mathrm{ZnO}$ thin film synthesized by sol gel method and its using in thin film solar cell”, Optik 124(2013) 4876-4879.
5. Hosseini et.al : "Effect of Ag doping on structural, optical and photo catalytic properties of $\mathrm{ZnO}$ nanoparticles": Cond-mat.mtrl-sci arXIV: 1508.000382V, 2015.

6. M.Karyaoui, A. Mmhamdi, H.Kaouach, A. Labidi, A. Boukhachem, K.Boubaker, M. Amlouk, R. Chtourou., Some physical investigation on silver- doped $\mathrm{ZnO}$ sprayed thin films, Material science in semiconductor processing, 30(2015) pp-255-262.

7. Mangesh Lenjwar et.al. : "Enhanced performance of Ag doped $\mathrm{ZnO}$ and pure $\mathrm{ZnO}$ thin film DSSCs prepared by solgel spin coating", Inorganic and nonmetal chemistry 2017 vol 47 , no. 7, 1090-1096

8. M.A. Khalid and H.A.Jassem, "Electrical and optical properties of polycystalline Ag-doped CdS thin films", Acta Physica Hungarica, 73(1) pp 29-34,1993

9. H. Katagiri, K.Jimbo, W.S.Maw,K. Oishi, M. Yamazaki, H. Araki,A.Takeuchi, Development of CZTS based thin film solar cell, Thin Solid films, vol 517,issue 7, 2009,pp $2455-2460$

10. Shubam Chandel, Ajan P.R, Annie Joseph V, V P N Nampoori, P Radhakrishnan, "A study of $\mathrm{CdS}$ and $\mathrm{Ag}$ doped CdS prepared through CBD technique", International conference on fiber optics and photonics, optical society of India 2012.

11. Sergio R. Ferra-Gonzalez et al, "Optical and structural properties of $\mathrm{CdS}$ thin films grown by chemical bath deposition doped with $\mathrm{Ag}$ by ion exchange", Optik 125(2014) 1533-1536.

12. Anant H. Jahagirdar, Ankur A. Kadam and eelkanth G. Dhere." Role of $\mathrm{i}-\mathrm{ZnO}$ in optimizing open circuit voltage of CIGS2 and CIGS thin film solar cell", Proceedings of the Conference Record of the $4^{\text {th }}$ IEEE World Conferenceon Photovoltaic Energy Conversion, 2006, pp.557-559.

13. Marc Burgelman, Koen Decock, Alex Niemegeers, Johan Verschraegen, Stefaan Degrave -SCAPS manual. Version: 17 February 2016

14. M. Burgelman, P. Nollet, S. Degrave, "Modelling polycrystalline semiconductor solar cells", thin solid film, 361-362(2000) pp. 527-532

15. Abdelbaki Cherouana, Rebiha Labbani: "Study of CZTS and CZTSSe solar cell for buffer layer selection": Applied Surface Science, 4 May 2017

16. Springer handbook of electronic and photonic materials, ISBN 0387-26059-5.

17. Sudipto Saha et al, "Performance of CZTSSe Solar cell with various Mole fractions of Sullfur for different buffer layers", $4^{\text {th }}$ ICDRET, Jan-2016.

18. Atul Kumar and Ajay D. Thakur, "Analysis of SnS2 buffer layer and $\mathrm{SnS}$ back surface layer based CZTS solar cells using SCAPS", Research gate publications/283043296, Oct-2015.

19. Darvish Zadesh P, Sohrabpoor H, Gorji NE. Numerical device simulation of carbonnanotube contacted CZTS solar cells. Opt Quant Electron. Oct 2016; 48-480.

20. Sudipto Saha, Ramiraj C.Shahidul Hassan, “ Improvement of the Output Performance of CZTS Thin Film Solar Cell" 2nd International Conference on Electrical, Computer \& Telecommunication (ICECTE),2016,Dec,Rajshai.

21. Mohammad Sijanur Rahaman Robin and Md. Mizanur Rahaman: "A Comparative Performance Analysis of CdS and In2S3 Buffer Layer in CIGS Solar Cell": IEEE Xplore: 16 March 2017, ISBN Information: Electronic ISBN: 978$1-5090-5785-6$ 
22. Abu Shama Mohammad Miraz, Md. Mortuza Faruk and Muhammad Asad Rahman. "Numerical Analysis of Deep Level Defects in Cu2ZnSnS4 (CZTS) Thin Film Solar Cells ": 2015 3rd International Conference on Green Energy and Technology (ICGET)

23. Y. Sanchez et al. " Advanced hybrid buffer layers for CZTS solar cells", Conference paper: 978-1-5090-27248/16/ C2016 IEEE ,pp 1511-1515

24. T. Minemoto et al. "Theoretical analysis of the effect of conduction band offset of window /CIS layer on performance of solar cell using device simulation", Solar energy materials and solar cells, 67(2001) 83-88.

25. Rafee Mahbub et al, "Simulation of CZTS thin film solar cell for different buffer layer for high efficiency performance", SAJET, vol2, no 52(2016), 1-10.

26. Omar A.M. Abdelraouf, Nagesh K Allam: "Nanostructuring for enhanced absorption and carrier collection in CZTS based solar cells: coupled optical and electrical tunneling": Optical materials 54(2016) pp 84-88.

27. Hong Zhang, Shuying Cheng, Jinling Yu, Haifang Zhou, Hongjie Jia: "Prospects of $\mathrm{Zn}(\mathrm{O}, \mathrm{S})$ as an alternative buffer layer for $\mathrm{Cu} 2 \mathrm{ZnSnS} 4$ thin-film solar cells from numerical simulation" : Micro \& Nano Letters, 2016, Vol.1, Iss.7,pp 386-390. 